\title{
The Relationship between Leadership Style of High Performance School towards Professional Learning Community (PLC)
}

\author{
Nor Azlin Ibrahim¹, Mohd Izham Mohd Hamzah²*, Jamalull Lail Abdul Wahab² \\ ${ }^{1}$ Faculty of Education, National University of Malaysia, Bangi, Malaysia \\ ${ }^{2}$ Centre of Education Leadership \& Policy, National University of Malaysia, Bangi, Malaysia \\ Email: *ezlin7967@gmail.com
}

How to cite this paper: Ibrahim, N. A., Hamzah, M. I. M., \& Wahab, J. L. A. (2019). The Relationship between Leadership Style of High Performance School towards Professional Learning Community (PLC). Creative Education, 10, 2742-2749. https://doi.org/10.4236/ce.2019.1012200

Received: October 18, 2019

Accepted: November 25, 2019

Published: November 28, 2019

Copyright $\odot 2019$ by author(s) and Scientific Research Publishing Inc. This work is licensed under the Creative Commons Attribution International License (CC BY 4.0).

http://creativecommons.org/licenses/by/4.0/

(c) (i) Open Access

\begin{abstract}
This analysis centered on defining the level of transformational leadership of the principals and the degree of the practice of the Professional Learning Community (PLC) in High-Performance secondary schools. Also, this research examined the diversity in the level of transformational leadership of principals based on demographic-graphical constituents, specifically tenure of service and course attendance, next, viewed at the relationship between transformational leadership and the practice of the Professional Learning Community. This research adopted a survey method employing a questionnaire for 48 principals. This data was examined utilizing version 22.0 SPSS. These conclusions imply that nearly all principals style transformational leadership with a mean score of 4.60 and that PLC practices have been performed very often by teachers with mean scores higher than 3.67. The Pearson correlation test revealed that the relationship between transformational leadership and the practice of the professional learning community was compelling and strong $(\mathrm{r}=0.534, p<0.01)$.
\end{abstract}

\section{Keywords}

Transformational Leadership, Professional Learning Community, High-Performance School (HPS)

\section{Introduction}

In line with the times, the education system in Malaysia is also regularly accepting modifications and enhancements. The transformations are competent in creating a quality workforce with superior personal characteristics such as innovative, productive, skillful, competitive and creative to overcome the challenges of the 
country and the contemporary globalization. A quality education system is anticipated to satisfy the government's wish to build lifelong learning. In this context, quality educational input is the guarantee of a quality system and this quality is the outcome of an effective administration system. The capacity of school leaders is also more involved with the extensive range and frequently challenged by modern advances. It is not simple to operate and perform transformations to the organization in improving quality education as it needs audacious leaders to make modifications (MohdIzham \& Norzaini, 2009). In order to support quality education, it is essential to design a learning society within every organization (Hallinger et al., 2014). Principals who are chief leaders in school administration demand a tremendous level of commitment and a healthy leadership style. Meyer's (2008) research affirmed that the behavior of principals influenced the Professional Learning Community. Next, it can recognize the best leadership manner and be capable of executing it suitably and efficiently according to the circumstances and target group in adjusting in the learning alliance. or later production of electronic products, and conformity of style throughout a journal paper. Margins, column widths, line spacing, and type styles are built-in; examples of the type styles are provided throughout this document and are identified in italic type, within parentheses, following the example. Some components, such as multi-leveled equations, graphics, and tables are not prescribed, although the various table text styles are provided. The formatter will need to create these components, incorporating the applicable criteria that follow.

\subsection{High-Performance School (HPS)}

The institution of the High-Performance School (HPS) has been done to accomplish the aspiration of the Ministry of Education (MOE) to ensure quality education, which is the third sub in the seven National Key Result Areas (NKRA). Therefore, on September 9, 2009, 100 schools were acknowledged as SekolahBerprestasi Tinggi or High-Performance Schools (HPS), including government and government aid schools. The quantity of HPSs has grown by 132 that comprises 68 primary schools from 64 secondary schools. HPS is described as a school of ethos, character, identity, unique and active in all perspectives of education and has a very distinct culture of work and excellence with a holistic and sustainably national globally competitive human capital. The chosen leaders will undergo training administered by the Aminuddin Baki Institute (IAB) to guarantee that they can execute their duty to assure that the purposes and aims of the HPS establishment are achieved. Besides, HPS is given the advantage of independent implementation, which is School-Based Management performed. It intends to intensify the quality of HPS through their innovation and creativity in the administration of education as required.

\subsection{Transformational Leadership}

The principal of the school is the central support of the school's purposes. It, too, plays a part in developing organizational potential relevant to school growth 
(Thoonen et al., 2012; Walker \& Ko, 2011). In High-Performance Schools (HPS), leaders are chosen based on their distinction and they will be guided to sustain HPS achievement and excellence. High-quality leadership is a necessity at HPS to guarantee quality teachers and build thriving human capital. To assure that every educational policy is entirely realized at the HPS level needs, it calls for powerful headmaster leadership. Effective leadership introduces leadership styles, such as transformational and transactional leadership (Azlin et. al, 2014). These leadership techniques carry out activities to magnify the performance of teachers and students. Transformational leadership was founded by western researchers Burn (1978) to explain it as a process by which leaders and staff grow each other to heighten their motivation. Leaders who follow this manner are ideal and have tremendous moral values, particularly in the fields of equity and equality. This notion of transformational leadership was more elaborated by Leithwood et al. (2005) suggest that this transformational leadership mode refers to leadership sharing between leaders and their subordinates. This partnership is based on certain levels of empowerment, guidance, motivation, monitoring and recognition. To that end, principals must be coached in order to learn and exercise leadership habits in schools. The conclusions of the Sathiyabama \& Sathiamoorthy (2016) investigation discovered that leaders who enrolled in NPQEL courses had a positive result on school leadership.

\subsection{Professional Learning Community (PLC)}

The learning community is comprised of principals, administrators and teachers who are engaged in embracing learning chances to assure that the learning demands of students are favorable and secure (Zuraidah, 2016). Western researcher Hord (1997) illustrates PLCs as activities in schools that explore knowledge and share constant learning that intends to enhance student success. According to him, the five elements followed by the PLC members were: 1) possessing a supportive leadership, 2) sharing vision and mission, 3) learning collectively and implementing, 4) a supportive environment and 5) sharing personal practice. The Professional Learning Community can improve the comprehension of the purpose and sense of teacher teaching for student attainment (Hipp \& Huffmann, 2003). It is especially appropriate for novice teachers because preceding researches observed that novice teachers encounter difficulties in classroom administration and require assistance and direction from experienced and skilled teachers to enrich their teaching and learning styles (Fariza \& Hazrati, 2019). It can also boost the teacher's professionalism and motivate students (Zanaton, 2017). Teachers who exercise PLC can intensify school distinction and design education organizations (Chong Chee Keong, Muhammad Faizal, \& Zuraidah, 2016). The organization's accomplishment in growing the capabilities and quality of the school is represented in the efficiency of the community's learning community.

\section{Research Questions}

1) What is the level of transformational leadership of the principals through 
the dimensions of ideal influence, motivational inspiration, intellectual stimulation and individual consideration?

2) Is there a contrast in the principal's transformational leadership practices based on demographic factors (length of service and attendance at the course) in HPS?

3) Is there a relationship between transformational leadership and teacher professional learning community practice?

\section{Methodology}

\subsection{Population and Sample}

The sample selection is crucial in any research. The sample selected should represent a population so that the study attended can be generalized and hence, the cluster random sampling approach and simple randomization are extremely apt (Cresswell, 2009). Due to the extensive population area of the whole of Malaysia, hence, the cluster random sampling method is split into five zones (South Zone, Central Zone, East Zone, North Zone and Sabah/Sarawak Zone). Basically, from each zone, the researcher will pick the state through a simple random technique. A sum of 48 principals at 48 High-Performance Schools in Malaysia were selected through the two methods.

\subsection{Instrument}

The method practiced in this study comes in a survey form. The questionnaire was the instrument applied in this research. There are two parts; Part A is demographic, especially the experience of being a principal, level of academic eligibility and numbers of attendance in the courses. Part B is a Transformational Leadership question adapted from the Multifactor Leadership Questionnaire (MLQ) (Bass \& Avalio, 2000). This questionnaire possesses 26 questions separated into four constructs (Supportive and shared leadership; shared goal, mission and vision; collective learning application and supportive condition).

\section{Research Findings}

Table 1 presents the levels of transformational leadership of principals, while Tables 2-4 record the level of principal's practice based on demographic factors (duration of service, academic performance and number of courses attended).

Table 1 offers the distribution of respondents according to the mean and standard deviation of four-dimensional transformational leadership practices, namely ideal influence, motivational inspiration, intellectual stimulation and individual judgment. Generally, the principals at HPS have practiced transformational leadership at a very high level with a mean reading of $4.60, \mathrm{SP}=0.305$. In detail, the most critical dimension practiced by principals is the dimension of individual judgment $(\min =4.67, \mathrm{SP}=0.366)$. This was accompanied by an intellectually stimulating dimension $(\mathrm{min}=4.65, \mathrm{SP}=0.399)$. The third highest dimension was motivational motivation $(\min =4.61, \mathrm{SP}=0.342)$ and the 
Table 1. Min, standard deviation and interpretation scores of the transformational leadership dimensions.

\begin{tabular}{cccc}
\hline $\begin{array}{c}\text { Transformational } \\
\text { leadership dimensions }\end{array}$ & Mean & Standard deviation & Interpretations of Scores \\
\hline Ideal influence & 4.48 & 0.377 & Very high \\
Motivational Inspiration & 4.61 & 0.342 & Very high \\
Stimulate Intelligence & 4.65 & 0.399 & Very high \\
Individual consideration & 4.67 & 0.366 & Very high \\
Overall & 4.60 & 0.305 & Very high \\
\hline
\end{tabular}

Table 2. Differences in transformational leadership practices by principals based on service duration factors.

\begin{tabular}{ccccc}
\hline Length of service & Mean Rank & KhiKuasaDua & df & Sig. \\
\hline 1 - 3 Years & 16.39 & & & \\
4 - 6 Years & 21.25 & & & \\
7 - 10 Years & 22.00 & 6.933 & & \\
$11-15$ Years & 19.50 & & \\
more than 15 years & 9.52 & & \\
\hline
\end{tabular}

Table 3. Differences in transformational leadership practices by principals based on courses attended.

\begin{tabular}{ccccc}
\hline Number of Courses Attended & Mean Rank & KhiKuasaDua & df & Sig. \\
\hline Less than 5 times a year & 27.38 & & & \\
5 times a year & 12.20 & 9.797 & 2 & 0.07 \\
More than 5 times a year & 27.78 & & \\
\hline
\end{tabular}

Table 4. Min, standard deviation and interpretation scores of the professional learning community dimensions.

\begin{tabular}{cccc}
\hline $\begin{array}{c}\text { Dimensions of Professional } \\
\text { Learning Communities }\end{array}$ & Mean & Standard Deviation & $\begin{array}{c}\text { Interpretations } \\
\text { of Scores }\end{array}$ \\
\hline $\begin{array}{c}\text { Sharing and Support Leadership } \\
\text { Sharing goals, Mission and Vision }\end{array}$ & 4.48 & 0.377 & Very High \\
Collective Learning and Application & 4.65 & 0.342 & Very High \\
Sharing Personal Practice & 4.67 & 0.399 & Very High \\
Supporting Circumstance & 4.60 & 0.366 & Very High \\
Overall & 4.40 & 0.305 & Very High \\
\hline
\end{tabular}

ideal dimension of influence was the fourth step practiced by principals in HPS with a minimum reading.

Table 2 shows transformational leadership practices based on factors of service duration and shows the results of the Kruskal-Wallis test of transformation- 
al leadership practice based on the period of principal's service. The results show that there was no difference between the five service period categories with $\mathrm{X} 2$ values $(\mathrm{df}=4, p>0.05)=6.933$. Significant value is 0.139 which is greater than significant value. Therefore, this test fails to reject the null hypothesis. This means that the transformational leadership practices of principals do not differ significantly in terms of service duration

Table 3 shows the results of the Kruskal-Wallis test of transformational leadership practice based on the number of courses attended by principals. The findings show that there was no difference between the three categories of courses attended by principals with $\mathrm{X} 2$ values $(\mathrm{df}=2, p>0.05)=9.797$. Significant value is 0.0 .7 which is greater than significant value. Therefore, this test fails to reject the null hypothesis. This means that the transformational leadership practices of principals do not differ significantly based on the number of courses attended.

Table 4 manifests the respondents' distribution according to the mean and standard deviation of the five dimensions of the professional learning community. Overall, teachers in HPS practiced the professional learning community at a high level with a mean reading of $4.40, \mathrm{SP}=0.330$. In detail, the most important dimension practiced by teachers was personal practice sharing (mean $=$ $4.67, \mathrm{SP}=0.366)$. Followed by the dimensions of collective learning and application $(\mathrm{min}=4.65, \mathrm{SP}=0.399$ ), followed by the dimension of goal, mission and vision $(\min =4.61, \mathrm{SP}=0.342)$, then the supporting dimensions $(\min =4.60, \mathrm{SP}=$ $0.305)$ and the last dimension to practice was shared and supportive leadership $(\min =4.48, \mathrm{SP}=0.377)$.

Table 5 shows the relationship between transformational leadership and the professional learning community. The study found that there was a significant positive relationship between transformational leadership practice and the professional learning community $(r=0.534 ; p=0.000)$. The value of $r$ symbolizes that the strength of the relationship between transformational leadership and professional learning community is strong (Cohen, 1988).

Table 5. Relationship between transformational leadership and the professional and the professional learning community.

\begin{tabular}{|c|c|c|c|}
\hline & $\mathrm{R}^{2}$ & $\begin{array}{l}\text { Transformational } \\
\text { Leadership }\end{array}$ & $\begin{array}{l}\text { Professional Learning } \\
\text { Community }\end{array}$ \\
\hline \multirow{3}{*}{$\begin{array}{l}\text { Transformational Lea- } \\
\text { dership }\end{array}$} & Pearson Correlation & 1 & $0.534^{\star *}$ \\
\hline & Sig (2-tailed) & & 0.00 \\
\hline & $\mathrm{N}$ & 48 & 48 \\
\hline \multirow{3}{*}{$\begin{array}{l}\text { Professional Learning } \\
\text { Community }\end{array}$} & Pearson Correlation & $0.534^{\star *}$ & 1 \\
\hline & Sig. (2-tailed) & 0.000 & \\
\hline & & 48 & 48 \\
\hline
\end{tabular}

${ }^{* *}$ Correlation is significant at the 0.01 level (2-tailed). 


\section{Implications}

Based on the analysis attended, there is an important positive relationship between transformational leadership and the professional learning community. The level of leadership practice executed by principals in HPS is at a very high level. Likewise, the professional learning community practiced by teachers in HPS is at a very high level. It notes that the leadership style exercised by HPS principals has impacted the organization. As we understood, HPS is a school that holds the distinction of its students each year. Quality teachers are competent in producing quality students. The work of the professional learning community followed at HPS is at an all-time high, which can raise student and school worth. The achievement and effectiveness of this professional learning community are the outcome of dynamic leadership behavior of transformational leadership. Ergo, in order to employ transformation and to establish a learning organization through the implementation of the professional learning community, the school leaders need to foster a transformational leadership style rather than any other leadership fashion.

\section{Acknowledgements}

The researchers would like to acknowledge the Ministry of Higher Education (MOHE) for the financial funding of this research through Fundamental Research Grant Scheme (FRGS) [Code: FRGS/1/2016/SSI09/UKM/02/9], Research Grant FPEND 1 (GG-2019-031) and PP-FPEND-2019.

\section{Conflicts of Interest}

The authors declare no conflicts of interest regarding the publication of this paper.

\section{References}

Azlin, N., Jamallulail, M. S., \& Norhayati (2014). AktivitiKepimpinanPengetua di Asia Tenggara: Analisis Data Kajian TIMSS 2011. Prosiding Seminar Nasional Pengurusan dan Kepimpinan Pendidikan ke-20, 183, 193.

Chong, C. K., Muhammad, F. A. G., \& Zuraidah, A. (2016). Amalan Komuniti Pembelajaran Profesional (KPP) Disekolah Berprestasi Tinggi (SBT) Malaysia: Sebuah SekolahJenis Kebangsaan Cina (SJKC) Di Sarawak. Jurnal Kepimpinan Pendidikan, 3.

Cohen, J. W. (1988). Statistical Power Analysis for the Behavioral Sciences (2nd ed.). Hillsdale, NJ: Lawrence Erlbaum Associates.

Cresswell, J. W. (2009). Research Design: Qualitative, Quantitative, and Mixed Methods Approaches. London: SAGE Publications.

Fariza, K., \& Hazrati, H. (2019). Challenges and Support for the Development of Novice Teachers' Professional Identities. Proceeding of the International Conference on Educational Technologies (ICEdu Tech 2019).

Hallinger, P., Moosung, L., \& James, K. (2014). Exploring the Impact of School Principals on Teacher Professional Communities in Hong Kong. Leadership and Policy in Schools, 13, 229-259. https://doi.org/10.1080/15700763.2014.901396 
Hipp, K. K., \& Huffman, J. B. (2003) Professional Learning Communities: Assessment Development-Effects. Kertasdibentangkandalam the Annual Conference of the International Congress for School Effectiveness and Improvement. Sydney, Australia.

Hord, S. (1997). Professional Learning Communities: What Are They and Why Are They Important? Issues about Change, 6, 23-45.

Meyer, L. H. (2008). An Examination of Leadership Behaviors of Lutheran High School Principals that Impact the Implementation of Professional Learning Communities. Mt Pleasant, MI: Central Michigan University.

MohdIzham, M. H., \& Norzaini, A. (2009). Pandangan Pentadbirterhadap Implementasi Proses Perubahan Terancang pada Sekolah Bestari di Malaysia. Jurnal Pendidikan Sains Sosial dan Kemanusiaan, 2, 75-88. (In Malay)

Sathiyabama, S., \& Sathiamoorthy, K. (2016). Hubungan Antara BakatKepimpinan dan Kepim-pinan Hal TujuGraduan NPQEL. Jurnal Kepimpinan Pendidikan, 3, 24-41.

Thoonen, E., Sleegers, P., Oorta, F., \& Peetsmaa, T. (2012). Building School-Wide Capacity for Improvement: The Role of Leadership, School Organizational Conditions, and Teacher Factors. School Effectiveness and School Improvement, 23, 441-460. https://doi.org/10.1080/09243453.2012.678867

Walker, A. D., \& Ko, J. (2011). Principal Leadership in an Era of Accountability: A Perspective from the Hong Kong Context. School Leadership \& Management, 31, 369-392. https://doi.org/10.1080/13632434.2011.606269

Zanaton, H. I. (2017) Pembelajaran Kolaboratif Guru. Bangi: Penerbit Universiti Kebangsaan Malaysia.

Zuraidah, A. (2016). Komuniti Pembelajaran Profesional di Malaysia. Amalan Penam-bahbaikan Sekolah. Penerbit Universiti Malaya. Kuala Lumpur, NJ: Erlbaum. 